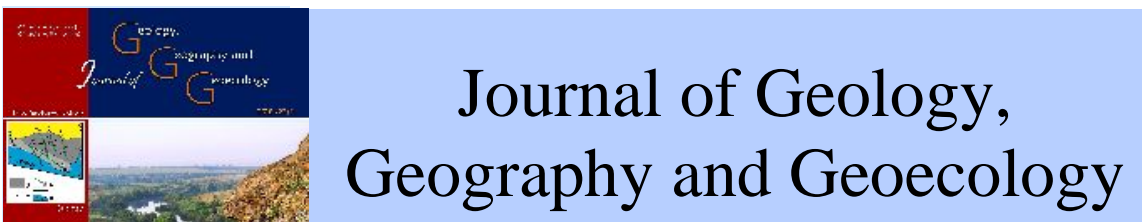

Journal home page: geology-dnu-dp.ua
ISSN 2617-2909 (print)

ISSN 2617-2119 (online)

Journ.Geol.Geograph.

Geoecology,

27(1), $138-147$

doi: $10.15421 / 111839$

Ulytsky ., Yermakov V., Buglak O., Lunova

Journ.Geol.Geograph.Geoecology,27(1), 138-147

\title{
Risk of man-made and ecological disasters at the filter stations in the Donetsk and Luhansk regions
}

\author{
. Ulytsky, V. Yermakov, O. Buglak, . Lunova
}

State Ecological Academy of Postgraduate Education and Management, Kyiv e-mail: Oksanalunova@gmail.com

\author{
Received 14.04.2018; \\ Received in revised form 03.05.2018; \\ Accepted 26.05.2018
}

Abstract. The ecological situation in the territories of Donetsk and Luhansk regions in the context of the military conflict which began in early 2014 is unstable and requires a timely resolution. Military conflicts lead to a number of dangerous impacts on soils and landscapes, surface and underground waters, vegetation and fauna, and military actions significantly increase the risk of emergencies in industrial enterprises and infrastructural facilities. Conflicts occurring in industrially developed territories with a large number of environmentally hazardous enterprises and objects constitute a particular danger to the environment. This article considers critical infrastructural objects on the example of objects of water supply (filtering stations) of Donetsk and Luhansk regions. Damage to or destruction of these objects threatens national security, the economy, and the health and safety of the population. Water supply facilities require the attention and access of international experts for preventing man-made and ecological disasters. An expert evaluation was carried out to assess the environmental threats and risks, existing threats were identified, an information and analytical system was developed, and recommendations were issued for minimizing the risks of man-made and ecological disasters. The current risk of an industrial accident with significant environmental consequences occurring in the course of the conflict is in the range from "low" to "average". According to an expert assessment within the framework of the OSCE Project Coordinator's study in Ukraine, in the course of development of any adverse scenarios, the potential danger of emergencies with serious environmental consequences remains significant. With large volumes of liquid chlorine emissions into the air, the population living in the zone of possible chemical contamination can be subjected to a severe degree of poisoning, which will lead to lethal consequences and a large number of victims. Economic development of Donetsk and Lugansk regions without the obligatory consideration of environmental factors is impossible. Ensuring the rehabilitation of the ecology of Donetsk and Luhansk oblasts is an important factor in bringing environmental protection activities in the region into line with the requirements of environmental safety in the current social and economic conditions and making these activities an integral part of the sustainable economic and social development of Ukraine.

Keywords: water supply, filter station, potable water, ecological safety, threats and risks, integral criterion.

\section{изики виникнення техногенно-екологічних к т строф н фільтрув льних ст нціях онецької т уг нської обл стей кр їни}

ерж вн екологічн $к$ демія післядіпломної освіти т упр вління, иїв, e-mail: Oksanalunova@gmail.com

нот ція. кологічн ситу ція н територіях онецької т уг нської обл стей в умов х воєнного конфлікту, що трив є 3 поч тку 2014 року, нест більн і потребує якн йшвидшого вирішення. оєнні конфлікти спричинюють цілу низку небезпечних впливів н грунти т л ндш фти, поверхневі і підземні води, рослинність і тв ринний світ, бойові дії зн чно збільшують ризики виникнення в рійних ситу цій н промислових підприємств х т інфр структурних об'єкт х. собливу небезпеку для довкілля ст новлять конфлікти, що відбув ються н промислово розвинених територіях з великою кількістю екологічно небезпечних підприємств т об'єктів. ст тті розглянуто об'єкти критичної інфр структури н прикл ді об'єктів водопост ч ння (фільтрув льних ст нцій) онецької т уг нської обл стей, недієзд тність бо знищення яких з грожують н ціон льній безпеці, економіці, здоров'ю т безпеці життедіяльності н селення. б’єкти водопост ч ння потребують ув ги і доступу міжн родних експертів для попередження н дзвич йних ситу цій екологічного т техногенного х $\mathrm{p}$ ктеру. ля з'ясув ння екологічних 3 гроз і ризиків визн чено н явні з грози, проведено експертне оцінюв ння, розроблено інформ ційно- н літичну систему т н д но рекоменд ції щодо мініміз ції ризиків виникнення техногенно-екологічних 138 
к т строф. уч сний ризик виникнення в ході конфлікту промислової в рії зі зн чними екологічними н слідк ми перебув $є$

в меж х від "низького" до "середнього". гідно з експертною оцінкою в р мк х дослідження оордин тор проектів в кр їні під ч с ре ліз ції будь-яких несприятливих сцен ріїв потенційн небезпек в рійних ситу цій із серйозними екологічними н слідк ми з лиш ється зн чною. великих обсягів викиду рідкого хлору в тмосферне повітря н селення, що прожив є в зоні можливого хімічного з р ження, може отрим ти в жкий ступінь отруєння, що призведе до лет льних н слідків т великої кількості жертв. кономічний розвиток онецької т уг нської обл стей без обов'язкового вр хув ння екологічних ф кторів неможливий. безпечення відновлення екології онецької т уг нської обл стей являє собою в жливий чинник для приведення природоохоронної діяльності в регіоні у відповідність із вимог ми екологічної безпеки в суч сних соці льних т економічних умов х т невід'ємну скл дову ст лого економічного т соці льного розвитку кр їни.

лючові слов : водопост ч ння, фільтрув льн ст нція, питн вод, екологічн безпек, з грози т ризики, інтегр льний критерій.

Introduction. The ecological situation in the territories of Donetsk and Luhansk regions in the context of the military conflict which began in early 2014 is unstable and requires an early resolution (Kravchenko ., 2015).

Military conflicts lead to a number of dangerous impacts on soils and landscapes, surface and underground waters, vegetation and fauna, and military actions significantly increase the risk of emergencies in industrial enterprises and infrastructural facilities. Conflicts occurring in industrially developed territories with a large number of environmentally hazardous enterprises and objects constitute a particular danger to the environment (Timochko ., 2016).

In the conditions of the lack of official information on the state of the environment in eastern Ukraine for assessing the damage done within the framework of the provision of services, all available sources of information were analyzed and summarized, which made it possible to form a vision of the level of environmental hazard.

Ensuring the rehabilitation of the ecology of Donetsk and Luhansk regions is an important factor in bringing environmental protection activities in the region into line with the requirements of environmental safety in the current social and economic conditions and making these activities an integral part of the sustainable economic and social development of Ukraine (Semerak O., 2018).

The level of security in a zone of military conflict is determined by the magnitude of the impact of the negative processes that occur and lead to social tension (environmental problems, social conflicts) in the country. Therefore, one of the strategic approaches to Ukraine's natural and technological safety in the area of hostilities should be the principle of non-zero risk, which requires the establishment of an effective system of economic mechanisms to ensure the safety of people, nature and society.

Economic development of Donetsk and Lugansk regions without the obligatory consideration of environmental factors is impossible.

As a result of the fighting on June 10, 2014, two workers of the Enterprise "Voda Donbassa" were wounded on the territory of the pumping station of the Siversky Donets-Donbas Channel and the water supply equipment was damaged. Accidents at the pumping stations led to the stoppage of water supply in several cities of Donetsk region. Volnovakha district remained completely without water. As a result of the bombing on July 2, the first rise of the Siversky Donets Donbas Channel was damaged, following which an employee of the Enterprise "Voda Donbassa" was fatally injured.

Material and methods. The purpose of this study is to find out the main problems of continuous provision of quality potable water for residents the territories of Donetsk and Luhansk regions, both those controlled and uncontrolled by the Ukrainian authorities, and the identification of threats and risks of man-made and ecological disasters at the filter stations and ways of avoiding them.

Modern ecological problems of the Donbas concern not only the violation of ecosystems or natural protected areas, but also the living conditions of the population, namely the prevention of pollution of sources of drinking water. The level of ecological and man-made danger of the Donbas has always been conditioned by the presence of critical infrastructure objects on its territory, which includes filter stations (Bondar ., 2017).

The main source of the water supply in the Donetsk and Luhansk regions is the river Siversky Donets. In the water supply system of the settlements of Donetsk and Lugansk regions, filter stations play an important role in purifying (lighting), disinfecting and bringing the chemical and biological composition of water extracted from the river Siversky Donets within the norms of drinking water in accordance with the requirements of the State Sanitary Norms and Rules "Hygienic requirements for drinking water intended for human consumption" (Rudko G., 2016).

Altogether in the Donetsk and Luhansk regions there are more than 20 filtering stations, which provide about 5.5 million people with drinking water, the location of the stations is shown in Fig. 1 


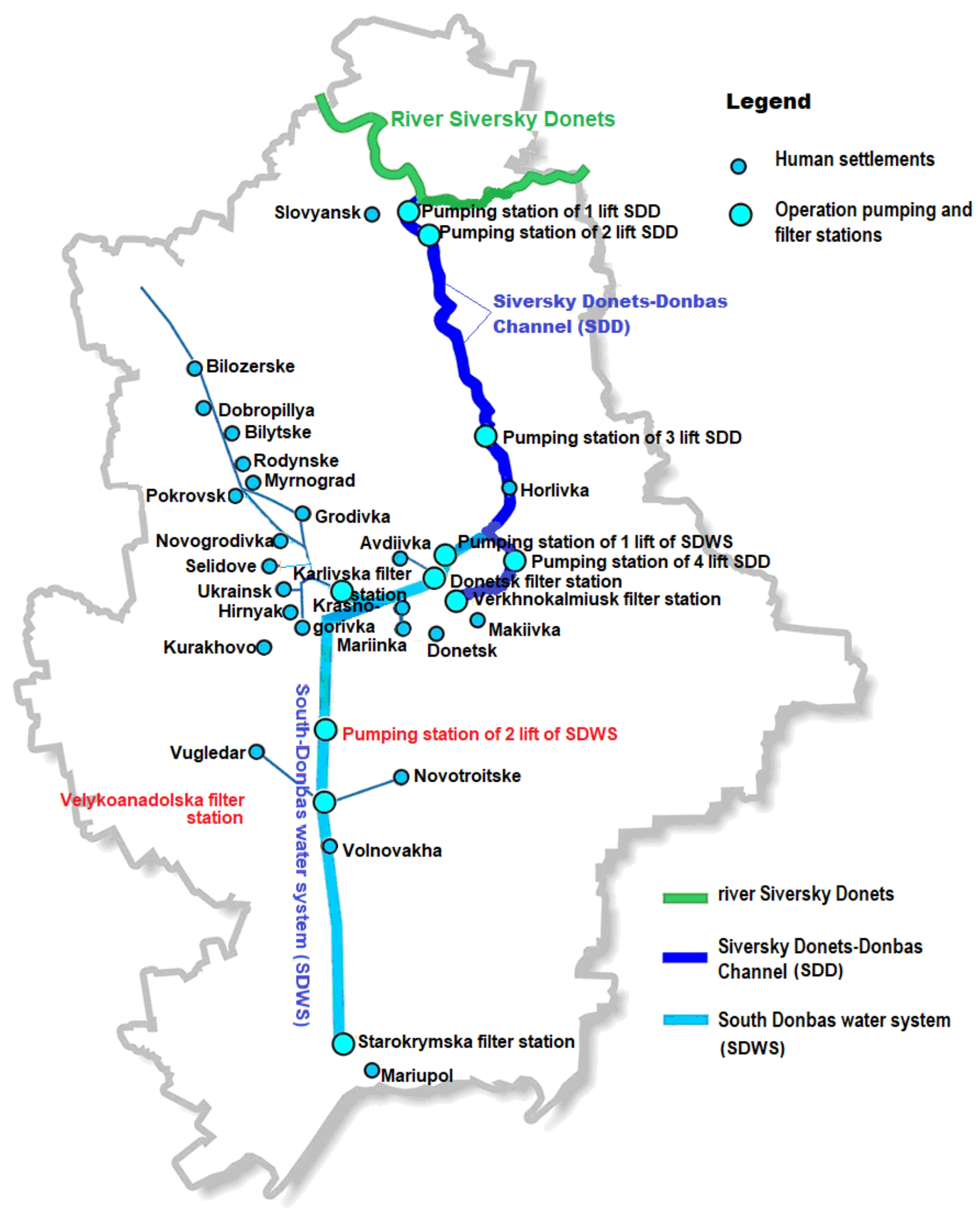

Fig. 1. Scheme of water supply in the Donetsk region

It should be noted that in the controlled territory, central executive bodies and local authorities, whose areas of management include filter stations, have the opportunity to control the development of events related to the operation of the facility, which allows them to take measures to prevent emergency situations, and in case of such situations, to quickly locate and eliminate them (Minprirodi, 2017).

Today the threat of damage to such objects is quite large because of the ongoing hostilities Particular attention should be paid to critical infrastructural objects located on the contact line or close to it. 
Given the location of objects, in case of an accident, the localization and elimination of the consequences of an emergency can be complicated because of the inability to access the damaged places. include:

The main filtering stations (FS) of the region

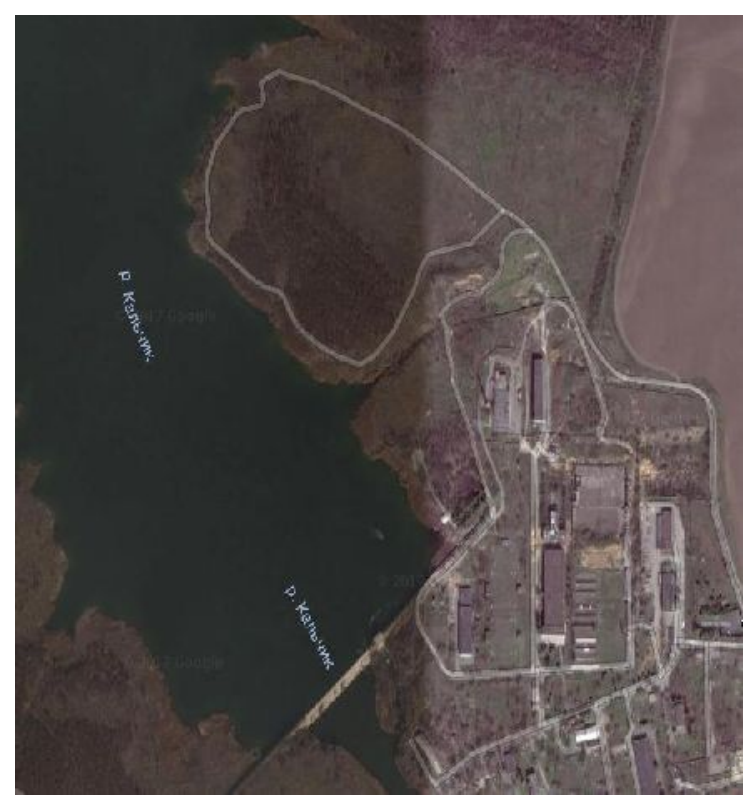

Fig. 2. Starokrymsk filter stations № 1, 2

Enterprise «Voda Donbassa»

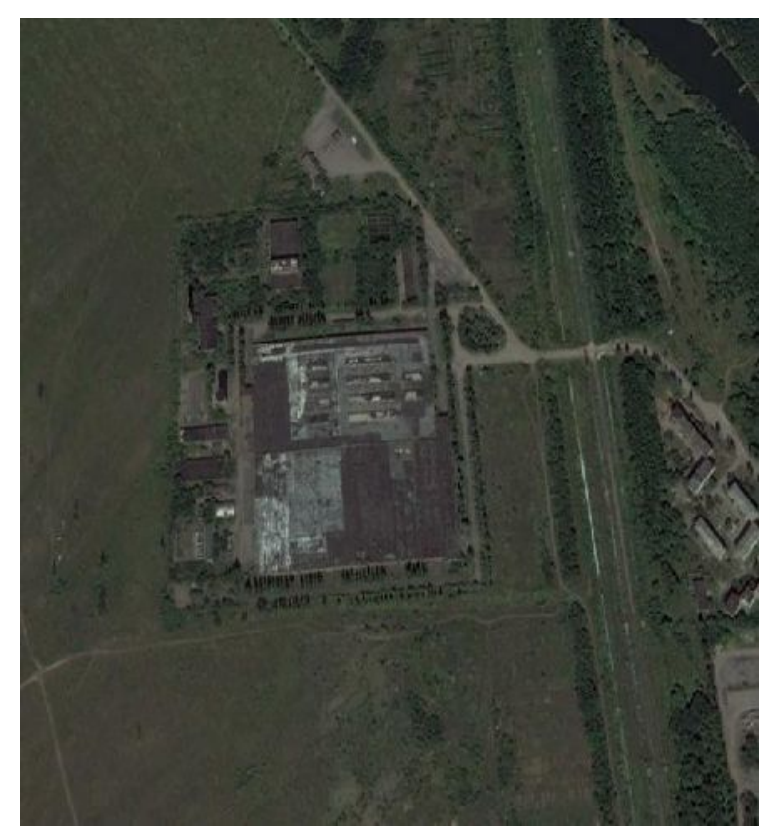

Fig. 3. Gorlivka filter stations № 1, 2 Enterprise «Voda Donbassa»
1. «Starokrymsk filter stations № 1, 2 Enterprise «Voda Donbassa»

2. «Gorlivka filter stations № 1, 2 Enterprise «Voda Donbassa»;

3. Donetsk filter station Enterprise «Voda Donbassa»;

4. Verkhnokalmiusk filter station Enterprise «Voda Donbassa»;

5. Zakhidna filter station Enterprise «Popasnyansky rayonnyi Vodokanal».

Starokrymsk filter stations are located near the city of Mariupol in Donetsk region (Fig.2). The main activity is cleaning and supplying drinking water to the population. Filter station № 1 was put into operation in 1936. Filter stations № 1, 2 together provide drinking water to about 500 thousand consumers in such settlements as Berdyansk, Shyroka Balka, Pokrovske, Kalynivka, Vynogradne and the city of Mariupol.

Gorlivka filter stations are located near the city of Gorlivka in Donetsk region (Fig.3). The main activity is cleaning and supplying drinking water to the population. Filter station № 1 was put into operation in 1958. The design capacity of the station № 1 is 68000 $\mathrm{m}^{3} /$ day, in fact $-47000 \mathrm{~m}^{3} /$ day. Filter station № 2 was put into operation in 1964 and together the stations provide drinking water to such cities as Gorlivka, Toretsk. 


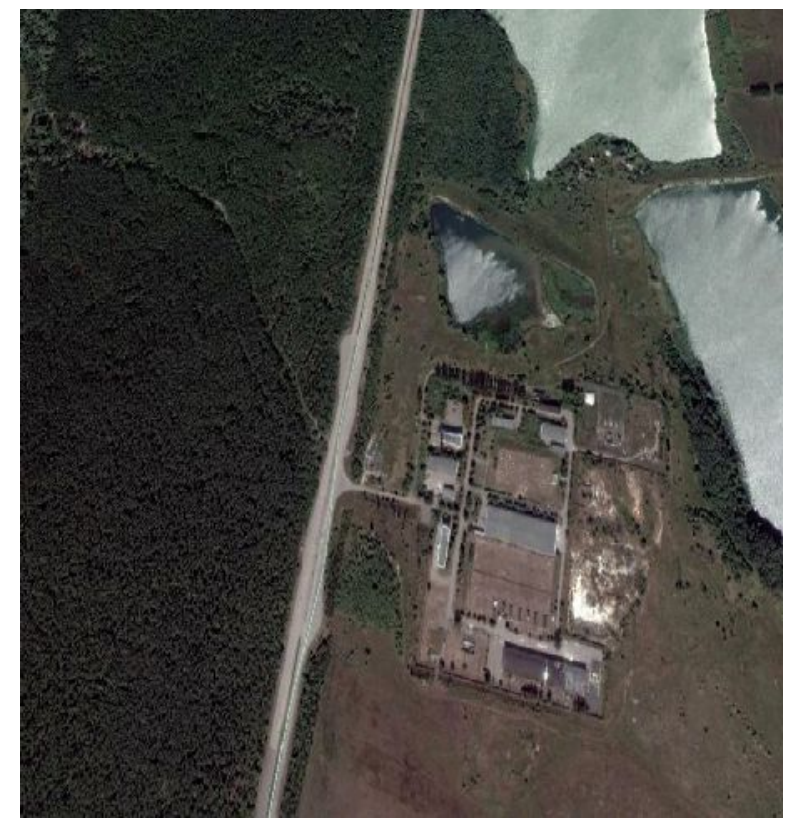

Fig .4. Donetsk filter station Enterprise «Voda Donbassa»

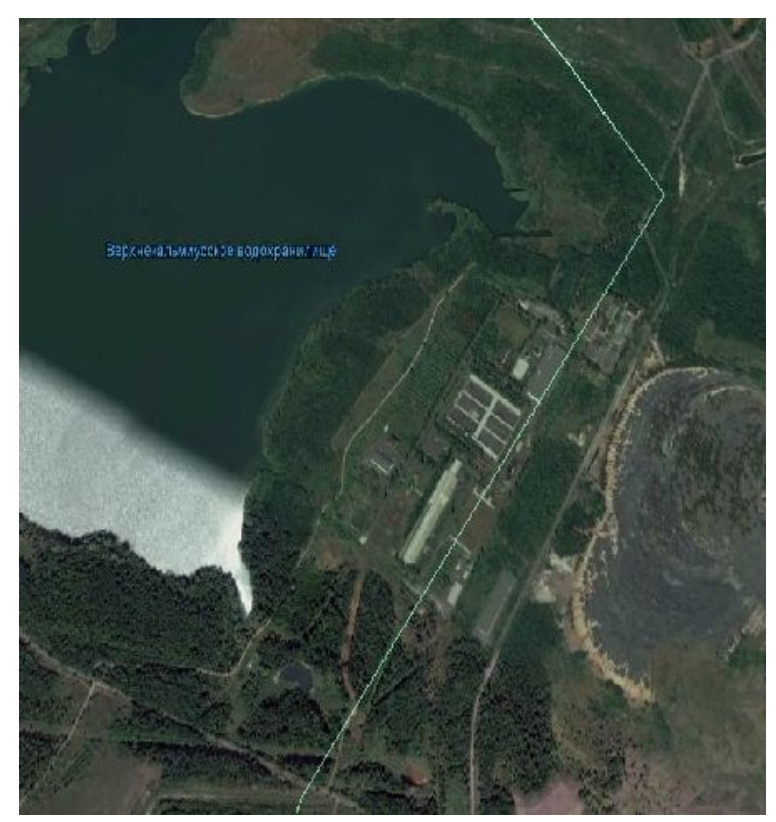

Fig. 5. Verkhnokalmiusk filter station Enterprise «Voda Donbassa»
Donetsk filter station is located near the Kruta Balka of Yasynuvata district in Donetsk region (Fig.4). The main activity is cleaning and supplying drinking water to the population. The filter station was put into operation in 1981. The filter station provides drinking water to such cities as Avdiivka, Mariinka, Krasnogorivka and, partly, Donetsk.
Verkhnokalmiusk filter station is located near the Mineralne of Yasynuvata district in Donetsk region and located on temporarily occupied territory (Fig.5). The main activity is cleaning and supplying drinking water to the population. The filter station was put into operation in 1959. 


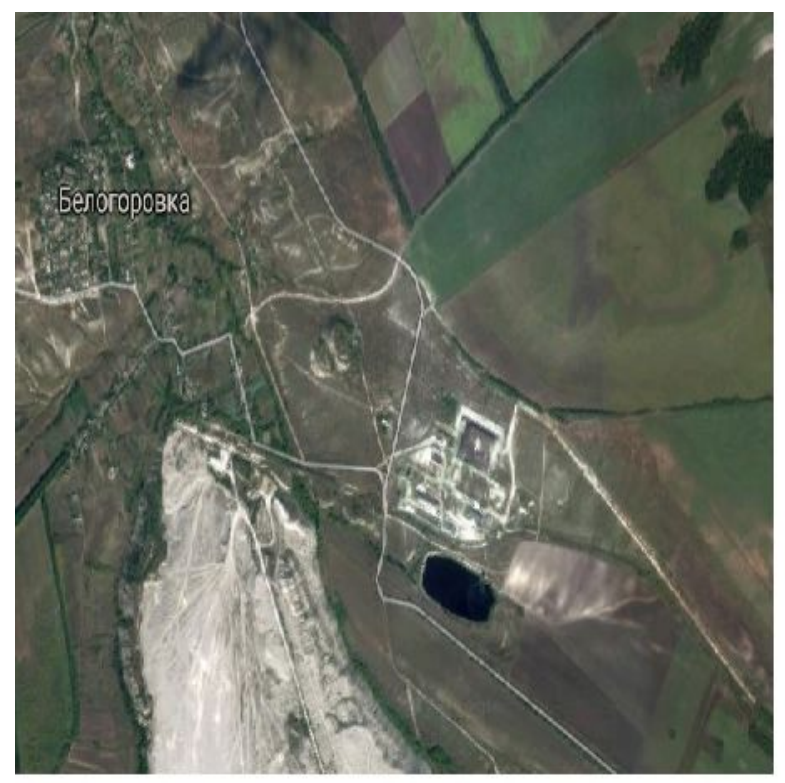

Zakhidna filter station is located near the Bilogorivka of Popasna district in Luhansk region (Fig.6). The main activity is cleaning and supplying drinking water to the population. The filter station was put into operation in 1992.

Fig. 6. Zakhidna filter station Enterprise «Popasnyansky rayonnyi Vodokanal»

In the process of water purification liquid chlorine is used. Filter stations have chlorine and reagent farms where liquid chlorine is stored in pressurized containers, which creates preconditions for the occurrence of man-made and ecological disaster in case of damage and depressurization of capacities. The technological indicators of the above-mentioned FS and the integral criterion for assessing threats and risks are given in Table 1.

Table 1. Integral criterion for estimating threats and risks of filtering stations

\begin{tabular}{|c|c|c|c|c|c|}
\hline № & Name & Location & $\begin{array}{l}\text { Capacity (in fact) } \\
\text { thousand, } \mathrm{m}^{3} / \mathrm{day}\end{array}$ & $\begin{array}{c}\text { Number of } \\
\text { consumers, } \\
\text { thousand }\end{array}$ & $\begin{array}{l}\text { Integral } \\
\text { criterion }\end{array}$ \\
\hline 1 & $\begin{array}{l}\text { «Gorlivka filter stations № 1,2 } \\
\text { Enterprise «Voda Donbassa» }\end{array}$ & Gorlivka & 187 & 370 & 1,219321734 \\
\hline 2 & $\begin{array}{c}\text { Donetsk filter station Enterprise } \\
\text { «Voda Donbassa» }\end{array}$ & $\begin{array}{l}\text { Kruta } \\
\text { Balka }\end{array}$ & 140 & 350 & 1,219321734 \\
\hline 3 & $\begin{array}{l}\text { Verkhnokalmiusk filter station } \\
\text { Enterprise «Voda Donbassa» }\end{array}$ & Mineralne & 320 & 550 & 1,219321734 \\
\hline 4 & $\begin{array}{c}\text { Zakhidna filter station Enterprise } \\
\text { «Popasnyansky rayonnyi } \\
\text { Vodokanal» }\end{array}$ & Bilogorivka & 60 & 1000 & 1,219321734 \\
\hline 5 & $\begin{array}{l}\text { «Starokrymsk filter stations № 1, } \\
2 \text { Enterprise «Voda Donbassa» }\end{array}$ & Mariupol & 105 & 500 & 1,219321734 \\
\hline
\end{tabular}

Discussion. Due to damage to pressure vessels which retain liquid chlorine its uncontrolled release into the atmosphere is possible, which will lead to pollution of the environment and poisoning of people (Bilyavsky G., 2006). It should be noted that one kilogram of liquid chlorine, when interacting with oxygen, is converted into 315 liters of gaseous chlorine, which is rapidly expelled by the wind. Taking into account the features of each of the filter stations, in the case of the release of liquid chlorine into the atmospheric air, the area of the zone of possible chemical contamination will be from $2 \mathrm{~km}^{2}$ to $30 \mathrm{~km}^{2}$. At the same time, the number of people in the predicted zone of chemical contamination in case of an accident in places of storage of chlorine can range from 0.3 thousand to 90 thousand people depending on the direction of the wind. 
Considering that the majority of these filter stations located close contact line, there is a high probability of damage and depressurization of containers of chlorine and its subsequent uncontrolled release into the atmosphere, which can lead to mass poisoning of the population. The population living in the zone of possible chemical contamination can receive a severe degree of poisoning in case of large volumes of liquid chlorine emissions into the air, and this can lead to lethal consequences and a large number of victims.

About 3 million people can remain without drinking water in the event of the shutdown of filter stations due to the disruption of technological process (leak of chlorine), which will lead to a significant complication of the humanitarian and sanitary-epidemiological situation in the region and will create preconditions for deterioration of the socio-economic situation.

To assess possible environmental threats and risks introduced we adopt the hierarchy analysis method (Lysychenko G., 2008).

The hierarchy analysis method is a method for solving multicriteria tasks with hierarchical structures that include both visible and imperceptible factors (Shmandiy V.M., 2013). This method was developed by the American mathematician Thomas Saati in the early 1990's and is based on pairwise comparisons (Saaty T.L., 1987). In addition, its application allows one to include in the hierarchy all the problems, knowledge and facts available to the researcher. The Saati interval scale was used to evaluate the threats using the pair comparison method (Zahedi F., 1986).

The algorithm of this method consists of the following steps:

- Formation of database of characteristics of criteria, factors and threats;

- Filling matrices of pairwise comparisons of elements of each level by a group of experts, which includes a system analyst;

- Definition of eigenvectors of matrices of pairwise comparisons and their normalization.
$P_{v p}=\left\{P_{v p l}, \ldots, P_{v p n}\right\}$ vector of threats and risks $(i=\overline{1, n}, j=\overline{1,3})$

is an integral assessment of the corresponding $i$ threat under the corresponding $j$ - criterion. For example, for the 1st threat:

$$
\begin{aligned}
& P_{v p 11}=k_{1} \cdot \overline{a_{11}}+k_{2} \cdot \overline{a_{12}}+k_{3} \cdot \overline{a_{13}}, \\
& P_{v p 12}=k_{1} \cdot \overline{a_{21}}+k_{2} \cdot \overline{a_{22}}+k_{3} \cdot \overline{a_{23}}, \\
& P_{v p 1 n}=k_{1} \cdot \overline{a_{n 1}}+k_{2} \cdot \overline{a_{n 2}}+k_{3} \cdot \overline{a_{n 3}} .
\end{aligned}
$$

On the basis of the computed priority vector $P_{v p i j}$ on the selected criterion of assessment and draw up a matrix of priorities.

$$
P=\left(\begin{array}{c|c:c:c:c:c|c} 
& 1 & 2 & 3 & \ldots & L & \\
\hline x_{1} & P_{v p_{11}} & P_{v p_{12}} & P_{v p_{13}} & \ldots & P_{v p_{1 L}} & \\
\ldots & \ldots & \ldots & \ldots & \ldots & \ldots & \ldots \\
x_{i} & P_{v p_{i 1}} & P_{v p_{i 2}} & P_{v p_{i 3}} & \ldots & P_{v p_{i L}} & \\
\ldots & \ldots & \ldots & \ldots & \ldots & \ldots & \ldots \\
x_{n} & P_{v p_{n 1}} & P_{v p_{n 2}} & P_{v p_{n 3}} & \ldots & P_{v p_{n L}} & \\
\hline & & & & & &
\end{array}\right)
$$

The criteria used are the following:

- criterion for assessing the source of the threat;

- criterion for assessing the level of threat impact;

- criterion for assessing the spread of the threat.

For the assessment of environmental threats and risks, an information and analytical system was developed and, together with a representative of the The Ukrainian Civil Protection Research Institute (UkrCPRI), an expert evaluation was made on the following hierarchical tree, shown in Fig. 7. 


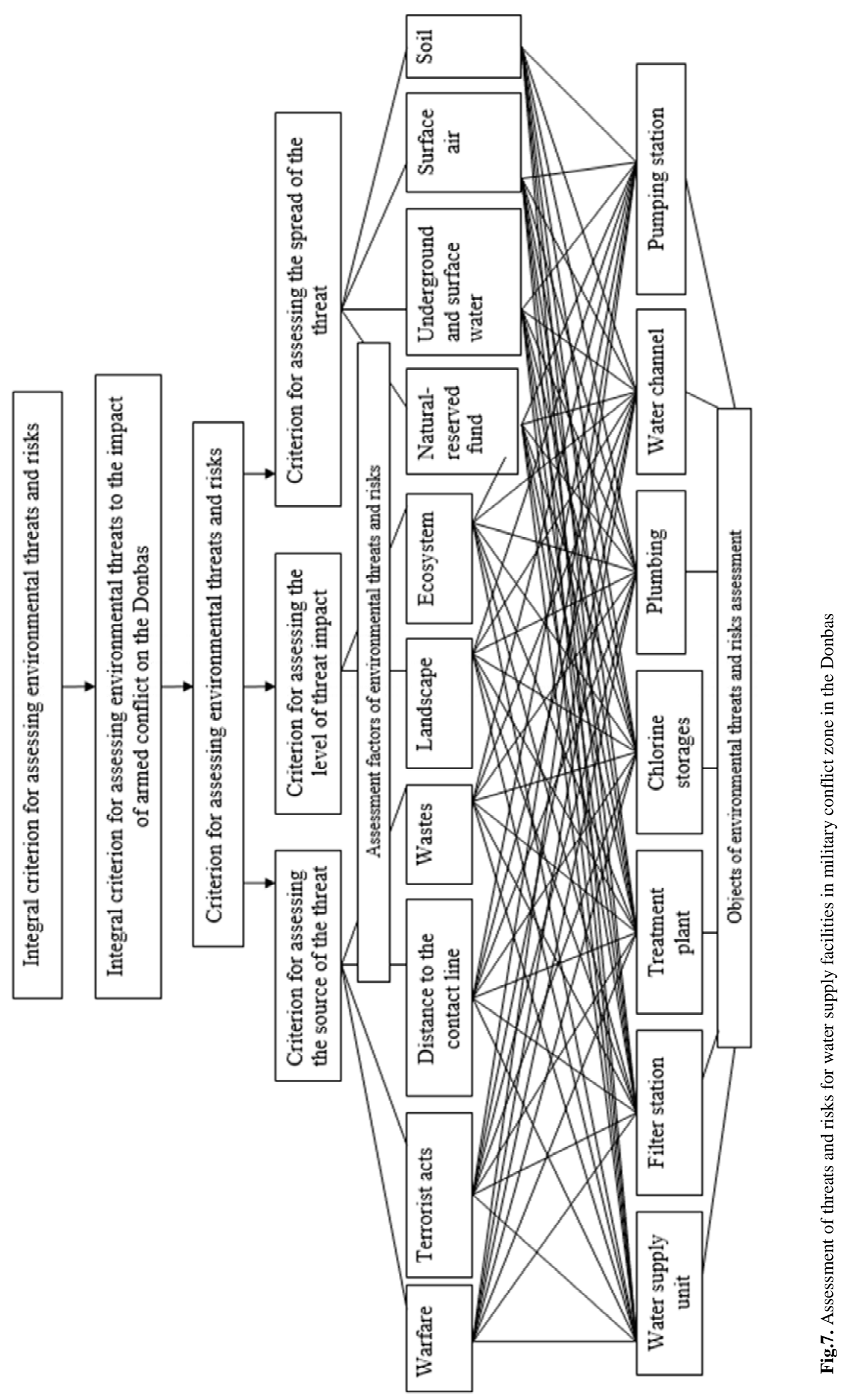


Conclusion. According to the results of research on the environmental situation on the territory of Donetsk and Luhansk region, it has been established that armed conflict has considerably worsened the situation with regard to the safe functioning of critical infrastructural objects (filter stations). The level of threat and risk assessment reached 1.2.

Since the beginning of the conflict there have been recorded more than 500 accidents and violations of the normal mode of operation of the critical infrastructural objects, some of which created environmentally hazardous situations. Significant numbers of them remain potential sources of emergency pollution.

The current risk of an industrial accident with significant environmental consequences occurring in the course of an industrial accident ranges from "low" to "average". According to an expert assessment within the framework of the OSCE Project Coordinator's study in Ukraine, in the course of development of any adverse scenarios, the potential danger of emergencies with serious environmental consequences remains significant.

In order to prevent the occurrence of ecological and man-made accidents and disasters, it is necessary to continuously monitor and analyze the functioning of facilities associated with the operation of filter stations located both in the controlled and temporarily occupied territory of Donetsk and Lugansk region.

It is also necessary to conduct detailed research on natural and artificial processes that have a negative impact on the environmental situation within the Donetsk and Luhansk regions, especially in the temporarily occupied territories due to the existence of interconnections between potentially high-risk objects located in the controlled and the temporarily occupied territory.

In order to minimize the risks of man-made environmental disasters associated with the operation of filter stations it is necessary:

- to develop plans for localization and elimination of the consequences of accidents to high risk objects, wherever such plans are absent;

- to take measures (technical calibration of capacities, planning and preventive maintenance of their services) in order to prevent depressurization of pressure vessels with chlorine;

- to change the technological process in the part of replacement of liquid chlorine for purification and filtration of water on sodium hypochlorite;

- to develop and implement alternative ways of providing drinking water to the population in case of the termination of the work of the filtering stations;

- to create "security zones" with a radius of 5 kilometers around each of filter stations in order to prevent their bombardment, due to their location very close to the contact line.

Summarizing the above, it should be noted that the problems of damage to the environment due to anthropogenic impact and the armed conflict in eastern Ukraine require increased attention to the solution of environmental problems at all levels of the organization of society and the search for the latest approaches to their solution.

\section{References}

Bilyavsky G., Furduy R., Kostikov I. (2006) Osnovy ekologii [Fundamentals of ecology] textbook, .:«Lybid», 408

Bondar . Ulytsky ., Yermakov V. (2017) Zvit pro nadannya poslugy "Provedennya otsinky ta vyvchennya tekhnogennogo stanu Donetskoi ta Luganskoi oblastei $\mathrm{z}$ metoyu rozrobky recomendatsii shchodo pryrodno-resursnogo vidnovlennya na ekologichnykh zasadakh" [Report on the provision of the service "Assessment and study of the ecological and manmade state of Donetsk and Luhansk regions in order to develop recommendations on environmental rehabilitation on an ecological basis»] Kyiv (in Ukrainian), 177

Denisov N. D.Averin, .Yushchuk, O.Ulytsky, ets (2017) Otsinka ekologichnoi shkody ta priorytety vidnovlennya dovkillya na skhodi Ukrainy [Assessment of environmental damage and environmental recovery priorities in eastern Ukraine] Organization for Security and Cooperation in Europe (in Ukrainian), 88

Kravchenko . (2015) Voenni diyi na shodi Ukrayini tsivilizatsiyni vikliki lyudstvu [Military actions in eastern Ukraine - civilizational challenges to human] Lviv: EPL, 136

Lysychenko G., Zabulonov Y., Khmil G. (2008) Pryrodnyi tekhnogennyi ta ekologichnyi ryzyky: analiz, otsinka, upravlinnya [Natural man-made and environmental risks: analysis, evaluation, management] . Joint-Stock Company «Vitol» (in Ukrainian), 544

Minpryrody posylyt monitoring povitrya, zemli i vody na Donbasi [The Ministry of Natural Resources will increase monitoring of air, land and water on the Donbas] Retrieved from https://menr.gov.ua/news/31471.html

Rudko G. Yakovlev . ets (2016) Ekologichna bezpeka vugilnykh rodovyshch [Ecological safety of coal deposits of Ukraine] monography, VVDBuk Rekm, Chernivtsi (in Ukrainian), 608

Saaty T. L. (1987) Concepts, theory and techniques: rank generation, preservation and reversal in the analytic hierarchy process//Decision Sciences Vol. 


\section{8. - P. $157-177$}

Semerak O. (2018) Povnotsinna reintegratsiya okupovanykh terytorii nemozhlyva bez ekologichnoi skladovoi [Complete reintegration of the occupied territories is impossible without an ecological component] Retrieved from https://menr.gov.ua/news/32116.html

Shmandiy V.M. ets (2013) Ekologichna bezpeka: pidruchnyk [Ecological safety: textbook]-Herson: Oldi plyus, 366
Timochko . (2016) Shchodo ekologichnogo monitoringu na Donbasi [Regarding environmental monitoring on the Donbas] Retrieved from https://hromadskeradio.org/programs/kyivdonbas/derzhava-ukrayina-ne-zaymayetsyaekologichnym-kontrolem-na-donbasi-tymochko

Zahedi F. (1986) The Analytic Hierarchy Process - a survey of the method and its applications//Interfaces Vol. 16, №4. - P. 96-108 